\title{
MANHAJ HAJI ABDUL RAHMAN LUBUK TAPAH DALAM PENULISAN ILMU FIQH: TUMPUAN TERHADAP KARYA PEDOMAN SOLAT BERJEMAAH
}

\section{Haji Abdul Rahman Lubuk Tapah's Method in Writing Fiqh: Focus on Pedoman Solat Berjemaah}

\author{
Ahmad Murshidi Mustapha ${ }^{1}$ \\ Mahyudin Daud ${ }^{2}$
}

\begin{abstract}
The development of madrasa (Islamic traditional institution) in Kelantan has produced many pious figures particularly in Islamic studies in classic scripture concept. Local Muslim scholars specialized in Islamic studies had contributed to these institutions whether by establishing their own madrasah or teaching at present madrasah. This research is conducted to present the personal biography of Haji Abdul Rahman Lubuk Tapah, Pasir Mas, Kelantan and his writing entitled "Pedoman Solat Berjemaah". He is seen as a major contributor to traditional religious study
\end{abstract}

\footnotetext{
Lecturer, Faculty Syariah and Jurisprudence, International Islamic University College Selangor, Bandar Seri Putra, 43000 Kajang, Selangor, ahmadmurshidi84@, gmail.com

2 Senior Lecturer, Academy of Islamic Studies, University of Malaya, Nilam Puri, 16010 Kota Bharu, Kelantan, muhyi@um.edu.my
} 
in Kelantan and his influence is still lively due to legacy of his great writings. Generally, this is a library-based research which using main sample based from the book of "Pedoman Solat Berjemaah". His writing structure ease readers to understand the content and to answer any questions related to rules and regulation of congregational in șalāh. The varieties of concept shown by Haji Abdul Rahman has made his book as the most favoured book especially in abode study until present time.

Keywords: Haji Abdul Rahman, Pondok Lubuk Tapah, Pedoman Solat Berjemaah, Islamic Traditional Institution

\section{PENGENALAN}

Para ulama sama ada dulu atau sekarang adalah golongan yang paling bersungguh-sungguh untuk berkhidmat kepada agama Allah dengan keupayaan masing-masing. Kebanyakan daripada mereka tidak hanya mengajar dan berdakwah melalui lisan tetapi turut berkarya. Setiap karya yang dihasilkan mempunyai metodologi tersendiri menurut kecenderungan dan faktor-faktor lain yang mempengaruhi penulisan mereka. Mengkaji dan mengetahui metodologi penulisan seseorang ulama dapat membantu memahami dengan lebih mudah maksud yang hendak disampaikan dalam sesuatu karya.

Haji Abdul Rahman Pondok Lubuk Tapah adalah salah seorang ulama tempatan yang terkenal dalam kalangan rakyat Kelantan dan menghasilkan karya bertulis. Beliau telah mengasaskan pengajian pondok di Kampung Lubuk Tapah pada tahun 1932 M. $^{3}$ Sistem pengajian di Pondok Lubuk Tapah merupakan salah sebuah pondok yang masih mengekalkan sistem pengajian pondok tradisional dalam bentuk yang asal berdasarkan metode halaqah dan kuliah. ${ }^{4}$ Pondok Lubuk Tapah adalah antara institusi terawal di negara kita yang membawa banyak reformasi dalam budaya kehidupan masyarakat, sama ada dalam konteks fizikal mahupun keilmuan. ${ }^{5}$

3 Ahmad Hassan, 'Sumbangan Pengajian Hadis terhadap Pembinaaan Insan: Suatu Kajian di Pondok Lubuk Tapah, Pasir Mas' (Disertasi Sarjana, Jabatan Sejarah dan Tamadun Islam, Akademi Pengajian Islam Universiti Malaya, 2005), 83.

4 Mohamad Suhaimi Mustapar, 'Metode Pengajian Fiqh di Pondok Lubuk Tapah, Pasir Mas, Kelantan' (Disertasi Sarjana, Jabatan Fiqh dan Usul, Akademi Pengajian Islam Universiti Malaya, 2008), 55-56.

5 Md Ramly Mahmood, 'Peranan Pondok dalam Pendidikan Islam di Kelantan: Suatu Kajian di Pasir Mas, Kelantan' (Disertasi Sarjana, Jabatan Syariah dan Tamadun Islam Akademi Pengajian Islam Universiti Malaya, 2005), 195. 
Antara karya beliau yang diterima baik dalam masyarakat Islam khususnya di Kelantan ialah kitab Pedoman Solat Berjemaah. Metodologi penyusunan dan penulisan karya tersebut yang istimewa membuatkan maksud yang hendak disampaikan menjadi jelas dan terang. Objektif kajian ini adalah mengupas secara mendalam biografi dan ketokohan Haji Abdul Rahman dan metodologi penulisan kitab Pedoman Solat Berjemaah. Kajian yang berbentuk kualitatif ini menggunakan kaedah pengumpulan data daripada data sekunder daripada dokumen-dokumen bertulis dan data primer melalui temu bual responden yang terpilih.

\section{BIOGRAFI HAJI ABDUL RAHMAN}

\section{Biodata Haji Abdul Rahman}

Haji Abdul Rahman bin Che Wan bin Senik bin Haji Mamat bin Lebai Latif, dilahirkan pada tahun 1902 bersamaan $1320 \mathrm{H}$. Keturunan beliau dapat di kesan sehingga ke generasi kelima bermula daripada ayah beliau Haji Che Wan, kemudian Senik, Haji Mamat, Abdul Latif dan Abdullah. Menurut Haji Mat Daud, satu-satunya adik kepada Haji Abdul Rahman yang masih hidup, moyang beliau iaitu Abdul Latif merupakan seorang yang pandai dalam ilmu al-Quran. ${ }^{6}$ Dengan kelebihan beliau dalam ilmu al-Quran, beliau telah dilantik sebagai pengajar al-Quran di istana Pattani. ${ }^{7}$ Hasil daripada perkahwinan dengan seorang perempuan di Kampung Salor, Pasir Mas, beliau dikurniakan dua orang anak lelaki iaitu Haji Mamat dan Haji Ismail. Haji Mamat dikurniakan tujuh orang anak iaitu Che Lah, Saman, Deraman, Mat Sih, Senik, Zainab dan Che Membaru. Daripada Senik melahirkan keturunan Haji Abdul Rahman. ${ }^{8}$

Haji Che Wan, anak kepada Senik merupakan seorang yang berpengaruh di kampung beliau. Menurut sumber, beliau mempunyai hanya dua beradik sahaja. Perkahwinan beliau tidak dapat dipastikan berapa kali dan juga berapakah bilangan sebenar isteri-isteri beliau. Hanya beberapa nama isteri beliau yang diketahui iaitu ibu kandung kepada Haji Abdul Rahman sendiri iaitu Hajjah Kalthum dan ibu kepada Haji Mat Daud, satu-satunya adik beliau yang masih hidup dan bermastautin di Mekah, iaitu Hajjah Maimunah. Hajjah

6 Mat Daud Haji Che Wan (adik Haji Abdul Rahman), dalam temu bual dengan penulis, 29 Februari 2012.

7 Mat Daud Haji Che Wan (adik Haji Abdul Rahman), dalam temu bual dengan penulis, 29 Februari 2012.

8 Muhammad Jusoh, 'Tuan Guru Haji Abdul Rahman Haji Che Wan seorang Tokoh Ulamak Pondok' (Latihan Ilmiah, Universiti Kebangsaan Malaya), 47. 
Maimunah merupakan isteri kedua terakhir Haji Che wan yang dikahwini beliau. Isteri beliau ini juga pernah berkahwin sebelum berkahwin dengan Haji Che Wan dan telah dikurniakan seorang anak, tetapi meninggal sebelum perkahwinan dengan Haji Che Wan. Antara isteri-isteri lain beliau yang hanya diketahui nama mereka ialah Khadijah dan Wo Lijoh. ${ }^{9}$

Daripada perkahwinan dengan Hajjah Kalthum, beliau dikurniakan tiga orang anak iaitu Che Mariam, Haji Abdul Rahman dan Sa'diah. Hasil perkongsian hidup dengan Hajjah Maimunah, beliau dianugerahkan dengan seorang anak lelaki iaitu Haji Mat Daud. Haji Che Wan juga dikurniakan seorang anak perempuan yang diberi nama Che Fatimah hasil perkahwinan beliau dengan Khadijah. ${ }^{10}$ Kesemua anak beliau adalah lima orang iaitu dua orang lelaki dan tiga orang perempuan.

Haji Abdul Rahman lebih dikenali dengan panggilan 'babo', ganti nama panggilan yang kebiasaannya digunakan kepada ulama-ulama di Pattani. Panggilan ini digunakan oleh anak cucu beliau dan panggilan ini juga digunakan oleh masyarakat sekitar dan akhirnya menjadi panggilan rasmi kepada beliau. ${ }^{11}$ Beliau juga dikenali sebagai 'Tok Guru Haji Abdul Rahman kitab' atau sinonimnya dengan loghat Kelantan, 'Tok Guru Haji Drome kitab'. Panggilan ini membezakan dengan besan beliau yang juga guru al-Quran di pondok tersebut iaitu Haji Abdul Rahman bin Haji Ngah. Guru al-Quran ini lebih dikenali dengan panggilan 'Tok Guru Haji Abdul Rahman Quran'. Selain itu, bagi masyarakat luar, Haji Abdul Rahman juga dikenali dengan panggilan 'Pok Mudo Haji' ${ }^{12}$ Beliau termasuk dalam kalangan ulama terkenal di negeri Kelantan yang seangkatan dengan Haji Che Hasan Lemal, Haji Abdullah Lati, Haji Abdullah Bunut Sarang Burung, Haji Muhammad Nor But, Dato' Haji Muhammad Nor Penambang dan ramai lagi. ${ }^{13}$

Haji Abdul Rahman mendirikan rumahtangga yang pertama dengan Hajjah Nik Nab bt Nik Mahmud yang berasal dari Kampung Padang Jelapang, semasa berumur 24 tahun dan isteri beliau ketika itu berumur 17 tahun. ${ }^{14}$ Hasil

9 Mat Daud Haji Che Wan (adik Haji Abdul Rahman), dalam temu bual dengan penulis, 29 Februari 2012.

10 Muhammad Jusoh, 'Tuan Guru Haji Abdul Rahman Haji Che Wan seorang Tokoh Ulamak Pondok', 45-46.

11 Lukman Haji Abdullah (cucu), dalam temu bual dengan penulis, 25 Februari 2012.

12 Mat Daud Haji Che Wan (adik Haji Abdul Rahman), dalam temu bual dengan penulis, 29 Februari 2012.

13 Pengasuh, Jamadilawal-Jamadilthani 1429 H, September-Oktober 1998.

14 Muhammad Jusoh, 'Tuan Guru Haji Abdul Rahman Haji Che Wan seorang Tokoh Ulamak Pondok', 49. 
perkahwinan dengan isterinya, Hajjah Nik Nab Bt. Haji Nik Mud, yang juga merupakan isteri pertama, beliau telah dikurniakan tujuh orang anak iaitu, Hajjah Halimah, Haji Abdullah, Haji Ahmad, Hajjah Aminah, Hajjah Aisyah, Hajjah Aidah, Hajjah Aliyah.

Daripada tujuh orang anak beliau dengan Hajjah Nik Nab bt Haji Nik Mud, tiga orang daripada mereka telah meninggal dunia. Haji Ahmad meninggal pada tahun 2000, Hajjah Aliyah pada tahun 2008 dan menyusul selepas itu Haji Abdullah pada April 2008. Isteri beliau ini pula meninggal sekitar tahun 1950an kerana sakit.

Haji Abdul Rahman mendirikan rumah tangga untuk kali kedua pada tahun 1960 dengan Wan Mas bt Thohir yang berasal dari Kampung Padang Tok Lar, Pasir Mas. Perkahwinan mereka berakhir dengan perceraian pada tahun 1969 M. ${ }^{15}$ Perkahwinan dengan isteri yang kedua beliau ini, tidak dikurniakan zuriat. Orang yang memainkan peranan dalam menyatukan mereka berdua adalah Che Daud yang merupakan penggawa Kampung Lemal ketika itu. Setelah sekian lama berkongsi hidup, beliau dan Wan Mas bercerai. Setelah bercerai sehinggalah kematian Haji Abdul Rahman, Wan Mas masih lagi tinggal di Pondok Lubuk Tapah. Wan Mas meninggal dunia pada tahun 2011 kerana sakit tua. ${ }^{16}$

Pada tahun 1969, beliau berkahwin untuk kali ketiga dengan Hajjah Zainab Bt. Mamat yang berasal dari Kampung Tandok Kubang Serdang, Bukit Panau. Ketika itu, beliau berumur 65 tahun dan isteri beliau berumur 21 tahun. Orang yang memainkan peranan dalam perkahwinan ini adalah anak beliau sendiri iaitu Haji Abdullah. Perkongsian hidup mereka dikurniakan dengan tiga orang anak iaitu, Haji Abdul Rahim, Adnan, Asyirah. ${ }^{17}$

Daripada ketiga-tiga isteri beliau, hanya Hajjah Zainab sahaja yang masih hidup sehingga sekarang. Hajjah Zainab yang dilahirkan pada tahun 1948 ini, merupakan seorang qariah dan pernah layak untuk ke pertandingan tilawah al-quran peringkat Kelantan dan beliau juga pernah memenangi pertandingan tilawah al-Quran peringkat zon. Sekarang masih lagi aktif mengajar al-Quran

15 Muhammad Jusoh, 'Tuan Guru Haji Abdul Rahman Haji Che Wan seorang Tokoh Ulamak Pondok', 51.

16 Abdul Rahim Haji Abdul Rahman (anak Haji Abdul Rahman), dalam temu bual dengan penulis, 29 Februari 2012.

17 Abdul Rahim Haji Abdul Rahman (anak Haji Abdul Rahman), dalam temu bual dengan penulis, 29 Februari 2012. 
yang dihadiri bukan sahaja oleh warga Pondok Lubuk Tapah bahkan juga masyarakat luar. ${ }^{18}$

\section{Pendidikan dan Guru-Guru}

Suasana hidup beragama dalam keluarga Haji Abdul Rahman menjadi salah satu pendorong kepada kejayaan beliau dalam pendidikan agama. Latarbelakang keluarga yang bercorak agama membentuk semangat dan keinginan beliau untuk belajar dan menguasai ilmu agama lebih-lebih lagi ayahnda beliau merupakan seorang imam di kampung tersebut. Dalam usia tujuh tahun, beliau dihantar ke sekolah Melayu Pasir Mas dan belajar di sana selama lima tahun. Setelah tamat pengajian, beliau dihantar untuk berguru dengan seorang ulama terkenal ketika itu iaitu Haji Muhammad Yusuf bin Ahmad al-Kelantani atau lebih dikenali dengan nama Tok Kenali. Haji Abdul Rahman dihantar ke Pondok Kampung Paya, Kubang Kerian untuk belajar dengan Tok Kenali selama lebih kurang empat hingga lima tahun. ${ }^{19}$

Ketika belajar dengan Tok Kenali, beliau mempelajari kitab-kitab kecil dan selepas daripada itu Tok Kenali sendiri yang menyuruh Haji Abdul Rahman ke Pondok Padang Jelapang. ${ }^{20}$ Pengajian beliau di Pondok Padang Jelapang yang letaknya kira-kira 3 kilometer dari rumah beliau, selama lebih kurang enam tahun, menonjolkan lagi keilmuan beliau. Ketika masih belajar di pondok tersebut dengan Haji Wan Ahmad bin Wan Abdul Halim, beliau telah diberi kepercayaan untuk menjadi salah seorang tenaga pengajar di pondok berkenaan. Di samping belajar, beliau juga memikul amanah untuk menyampaikan ilmu-ilmu agama di sana. ${ }^{21}$

Dapat disimpulkan bahawa guru-guru kepada Haji Abdul Rahman di sekitar Kelantan sebelum beliau ke Mekah ialah Haji Muhammad Yusuf Ahmad (1870-1933 M), Haji Wan Ahmad bin Wan Abdul Halim (1861-1934 M), Haji As'ad bin Haji Daud Kangkong (1886-1941 M), Haji Yaakub bin Ismail (1892-1971 M) dan Tok Ajong Sumatera.

\footnotetext{
18 Abdul Rahim Haji Abdul Rahman (anak Haji Abdul Rahman), dalam temu bual dengan penulis, 29 Februari 2012.

19 Muhammad Jusoh, 'Tuan Guru Haji Abdul Rahman Haji Che Wan seorang Tokoh Ulamak Pondok', 61-63.

20 Mohd Zaidi Abdullah (Ketua Penyelidik, Akademi Pencerahan Ulum Pondok dan Tamadun), dalam temu bual dengan penulis, 16 Mac 2012.

21 Muhammad Jusoh, 'Tuan Guru Haji Abdul Rahman Haji Che Wan seorang Tokoh Ulamak Pondok’, 63-64.
} 
Pada tahun 1927 dalam lingkungan umur 25 tahun, Haji Abdul Rahman berangkat ke Tanah Suci Mekah untuk meneruskan pengajian di sana. Berbekalkan perbelanjaan dari hasil titik peluh beliau, keluarga dan saudara mara, beliau dan isteri berangkat ke Mekah dan menghabiskan masa pengajian di sana selama empat tahun. Dalam masa yang sama, beliau sempat belajar dengan para ulama yang masyhur ketika itu sepanjang pengajian di Mekah. Antara ulama yang sempat beliau berguru dengan mereka ialah Sheikh 'Alī alMālikī (1870-1949 M), Sheikh Sayyid 'Abbās (1868-1934 M), Sheikh 'Umar Hamdān (1875-1949 M), Sheikh Muhammad Mukhtar al-A’thori Bogor (m. 1930 M), Sheikh Uthman Jalaluddin (1880/1882-1952 M), Tuan Guru Haji Syafie Kedah ${ }^{22}$ (m. 1953 M), Sheikh Mohd Ahyad bin Mohd Idris, Sheikh Ismail bin Abdul Qadir al-Fathani, Sheikh Sa‘̄̄d al-Yamanī.

Penguasaan beliau dalam ilmu agama mencakupi semua sudut. Kepakaran beliau dalam ilmu faraid agak menonjol sehinggakan pada masa tersebut di kawasan Pasir Mas, masalah faraid akan diajukan kepada beliau untuk diselesaikan. ${ }^{23}$ Pernah beliau didampingi oleh Dato' mufti Haji Ahmad Maher bin Haji Ismail bagi membuat perbincangan dalam masalah pusaka. ${ }^{24}$

Sekitar awal tahun 1930an hingga akhir 1950an, Haji Abdul Rahman menjadi ulama terkenal sebaris dengan beberapa ulama yang masyhur yang sezaman dengan beliau di sekitar jajahan Pasir Mas. Antara mereka ialah Haji Awang, Kampung Cherang atau Kampung Mat Lajin, Pak The Haji Yunus, Kampung Sakar, Haji Abdullah, Tal Tujuh, Haji Abdul Rahman, Tepi Sungai Tendong, Haji Ahmad, Batu Tiga dan Haji Abdullah, Lati. ${ }^{25}$

\section{Murid-Murid}

Ketinggian ilmu dan kesungguhan beliau dalam melahirkan para ulama pelapis telah terbukti dengan lahirnya beberapa ulama yang rmasyhur. Selain daripada anak beliau sendiri iaitu Haji Abdullah yang seterusnya menjadi pengganti beliau dalam menerajui pondok tersebut, terdapat beberapa orang lagi yang masyhur dalam meneruskan perjuangan ilmu Haji Abdul Rahman.

22 Muhammad Jusoh, 'Tuan Guru Haji Abdul Rahman Haji Che Wan seorang Tokoh Ulamak Pondok', 65-67.

23 Abdul Rahim Haji Abdul Rahman (anak Haji Abdul Rahman), dalam temu bual dengan penulis, 29 Februari 2012.

24 Muhammad Yunan Mahmud, Riwayat Hidup Tokoh Ulama Kelantan,(Kota Bharu: Yayasan Islam Kelantan, 1989), 103.

25 Abd Rahman Haji Abdullah, Pemikiran Islam di Malaysia (Kuala Lumpur: Dewan Bahasa dan Pustaka, 1998), 415. 
Sebilangan murid Haji Abdul Rahman berjasa dalam bidang keilmuan sebagaimana beliau, antara mereka ialah, Ustaz Haji Husin Ibrahim (bekas ADUN Bukit Tuku), Haji Hasan Che Musa (bekas imam tua masjid Pengkalan Chepa), Haji Daud bin Haji Abdullah Jambul, mubaligh dan guru di Pondok Perangkap, Bunut Susu, guru kelas tafaqquh di Masjid Muhammadi di Kota Bharu dan ahli Jemaah MAIK (m. 1990), Haji Zakaria Soh, imam Keliwat, Tanah Merah, Haji Ja'far bin Sulaiman, yang membuka pondok di Kertau Temerloh, Pahang, Haji Yusuf bin Haji Ya'qub, imam Lubok Tapah, Pasir Mas $^{26}$ dan Haji Rahim, Pondok Aur Cina, Pasir Mas. ${ }^{27}$

\section{Karya}

Selain melahirkan para ilmuan yang masyhur dengan ilmu agama, Haji Abdul Rahman juga meninggalkan beberapa buah hasil karangan yang digunapakai sehingga kini. Kitab-kitab yang ditinggalkan oleh beliau ialah:

1. Pedoman Solat Berjemaah

2. Kemanisan Sembahyang

3. Kelabaan Masa Kerana Menuntut Sentosa

Kesemua kitab ini ditulis dengan menggunakan tulisan jawi dan bahasa yang digunakan ialah bahasa Melayu yang sering digunakan di negeri Kelantan. ${ }^{28}$

\section{Sumbangan}

Haji Abdul Rahman sebagai pelopor institusi pondok di Kampung Lubuk Tapah telah menghidupkan suasana keilmuan yang bercorak tradisi. Bertahannya pondok yang diasas oleh beliau sehingga kini, menjadi simbol kebanggaan rakyat Kelantan umumnya dan masyarakat kampung tersebut khususnya. Sumbangan ilmu yang dicurahkan oleh beliau digunapakai sehingga kini sama ada dalam bentuk karangan mahupun para pelajar hasil keluaran pondok beliau.

26 Majlis Agama Islam dan Adat Istiadat Negeri Kelantan, Majalah Pengasuh, Jamadilawal-Jamadilthani 1429H, September-Oktober 1998M, 30.

27 Abdul Rahim Haji Abdul Rahman (anak Haji Abdul Rahman), dalam temu bual dengan penulis, 29 Februari 2012.

28 Muhammad Jusoh, Tuan Guru Haji Abdul Rahman Haji Che Wan seorang Tokoh Ulamak Pondok, 110. 


\section{Bidang Keilmuan}

Dalam konteks keilmuan, dapat disimpulkan bahawa bidang keilmuan adalah salah satu usaha beliau yang paling besar yang dicurah dan ditinggalkan untuk masyarakat umum. Karya beliau yang ditinggalkan, masih lagi digunapakai sehingga kini bahkan diterima baik oleh masyarakat. Curahan ilmu oleh beliau juga telah melahirkan ilmuan-ilmuan Islam yang menyambung perjuangan ilmu-ilmu Islam seperti Haji Ja'far bin Sulaiman dan Haji Rahim. Antara sumbangan keilmuan beliau yang masih dapat dikecapi sehingga kini adalah Pondok Lubuk Tapah yang masih utuh berdiri. Hasil yang dikeluarkan mampu meneruskan kembali perjuangan dakwah beliau sehingga ke hari ini.

Setelah kembali daripada Mekah setelah empat tahun berada di sana, beliau mencurahkan ilmu bukan sahaja di pondok beliau bahkan juga di sekitar kampung beliau dalam usaha menabur bakti kepada masyarakat. Walau bagaimanapun, beliau lebih banyak mengajar di pondok beliau berbanding dengan mengajar di luar. ${ }^{29}$ Ilmu yang dicurahkan oleh beliau tidak hanya melibatkan bidang usuluddin dan fiqh sahaja, bahkan juga aspek kerohanian atau tasawwuf. Dalam tahun 70an, beliau mengajar Kitab Hikam yang merupakan salah sebuah kitab tasawuf yang masyhur. Beliau meneruskan pemurnian rohani melalui kitab ini di pondok beliau sehingga meninggal dunia. $^{30}$

Cara pengajaran beliau adalah terang dan jelas sehingga orang yang berada di luar sekalipun boleh menadah kitab dengan baik. Waktu pengajaran beliau berdisiplin dan teratur. Selepas Subuh hingga jam sembilan adalah untuk murid-murid baru, jam sepuluh hingga jam dua belas tengahari untuk muridmurid peringkat pertengahan dan tinggi, selepas Zohor untuk kaum ibu, selepas Asar untuk murid peringkat tinggi dan selepas Maghrib untuk umum ${ }^{31}$.

Haji Abdul Rahman juga menyediakan waktu-waktu mengajar yang khusus untuk golongan-golongan yang tertentu. Beliau memperuntukkan untuk orang kampung pada setiap hari Selasa di antara Zohor hingga Asar. Pada setiap hari Ahad untuk murid-murid tua yang telah pun membuka pondok atau yang telah menjadi imam. ${ }^{32}$

29 Mat Daud Haji Che Wan (adik Haji Abdul Rahman), dalam temu bual dengan penulis, 29 Februari 2012.

30 Mohd Zaidi Abdullah (Ketua Penyelidik, Akademi Pencerahan Ulum Pondok dan Tamadun), dalam temu bual dengan penulis, 16 Mac 2012.

31 Muhammad Yunan Mahmud, Riwayat Hidup Tokoh Ulama Kelantan (Kota Bharu: Yayasan Islam Kelantan, 1989), 103.

32 Muhammad Yunan Mahmud, Riwayat Hidup Tokoh Ulama Kelantan, 101. 
Jadual 1: Kitab-kitab yang diajar oleh Haji Abdul Rahman

\begin{tabular}{|c|c|c|}
\hline Bil. & Bidang & Kitab-kitab \\
\hline 1 & Naḥū & $\begin{array}{l}\text { Matn al-Ājrūmiyyah, Mukhtașār, Mutammimah, Ibn } \\
\text { 'Aqūl, Yāsīn, Sheikh Khālid }\end{array}$ \\
\hline 2 & Tafsir & Al-Jalālayn, Kitāb al-Tashīl, al-Nasafì, al-Bayḍāwì \\
\hline 3 & Hadis & Al-Muwatt $\bar{a}$ \\
\hline 4 & Fiqh & 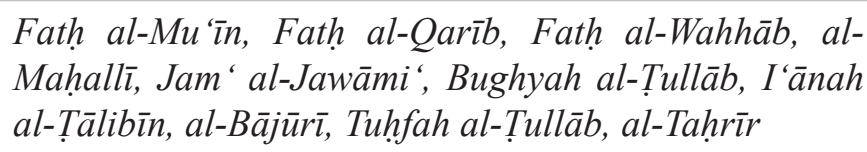 \\
\hline 5 & Tasawuf & $\begin{array}{l}\text { Hikam Ibn 'Ața' Allāh, Hidāyah al-Sālikīn, Ihyāa' 'Ulūm } \\
\text { al-Dīn }\end{array}$ \\
\hline 6 & Tauhid & Fath al-Majīd \\
\hline 7 & Sejarah & Itmām al-Wafā' \\
\hline 8 & Usul Fiqh & Al-Ashbāh wa al-Naẓā'ir \\
\hline
\end{tabular}

Sumber: Muhammad Yunan Mahmud, Riwayat Hidup Tokoh Ulama Kelantan.

\section{Bidang Dakwah}

Penubuhan Pondok Lubuk Tapah oleh beliau pada tahun1932 merupakan salah satu wasilah dalam penyampaian dakwah kepada masyarakat sekitar khususnya dan untuk masyarakat luar umumnya. Pengajian yang dijalankan sepanjang hari berbentuk kuliah umum dan khusus diikuti oleh segenap lapisan masyarakat. Skop dakwah yang digunakan oleh beliau tidak tertumpu kepada aktiviti pengajaran di pondok beliau sahaja. Dakwah secara penulisan juga digunakan melalui karangan beliau yang digunapakai sehingga kini iaitu Pedoman Solat Berjemaah, Kelabaan Masa kerana Menuntut Sentosa dan Kemanisan Sembahyang.

Selain aktiviti dakwah melalui pengajaran khusus di pondok dan karangan kitab, Haji Abdul Rahman juga menggunakan mimbar masjid di Masjid Lubuk Tapah. Selaku imam masjid berkenaan, beliau menggunakan mimbar tesebut sebagai ruang penyampaian ilmu dan nasihat terutama pada hari Jumaat. ${ }^{33}$ Beliau pernah ditawarkan jawatan kadi beberapa kali oleh Dato' Mufti Haji Ahmad Maher tapi ditolak dengan alasan beliau sibuk. ${ }^{34}$

33 Muhammad Jusoh, Tuan Guru Haji Abdul Rahman Haji Che Wan seorang Tokoh Ulamak Pondok, 109.

34 Muhammad Yunan Mahmud, Riwayat Hidup Tokoh Ulama Kelantan, 104. 


\section{Bidang Politik}

Penglibatan Haji Abdul Rahman dalam bidang politik bukan sekadar penglibatan sebagai ahli ataupun penyokong yang biasa. Sokongan padu yang diberikan oleh beliau kepada Parti Islam Semalaysia (PAS), tidak berbelah bagi, bahkan beliau sering dikunjungi oleh pemimpin-pemimpin parti ketika itu dan salah seorang daripada mereka adalah Haji Abdul Hadi, presiden PAS kini. Disebabkan faktor umur yang meningkat dan keinginan menjaga institusi pondok yang diasas, beliau mengurangkan keaktifan dalam parti tersebut. ${ }^{35}$

\section{Bidang kemasyarakatan}

Sebagai seorang yang disegani bukan sahaja di Kampung Lubuk Tapah, Haji Abdul Rahman diberi kepercayaan dalam segenap aspek yang melibatkan kemaslahatan masyarakat. Beliau antara yang berjasa dalam pembinaan jambatan yang menghubungkan antara Kampung Lubuk Tapah dan Kampung Surau iaitu kampung bersebelahan yang dipisahkan oleh sungai. ${ }^{36}$

Pembinaan Masjid Lubuk Tapah juga adalah satu sumbangan besar kepada masyarakat sekitar terutamanya dalam menjalankan aktiviti keagamaan. Berikutan runtuhnya surau di Kampung Surau, yang menjadi tumpuan masyarakat sekitar termasuk masyarakat Kampung Lubuk Tapah, sebuah surau baru didirikan di Kampung Lubuk Tapah yang dikini masih boleh dilihat berada di hadapan rumah Allahyarham Haji Abdullah. Setelah berlaku pertambahan penduduk dan keperluan yang makin bertambah, masjid yang lebih luas dibina untuk menampung kapasiti jemaah yang ramai dalam satusatu masa. ${ }^{37}$

Kemurahan hati beliau dapat dilihat menerusi sumbangan yang selalu beliau hulurkan terutamanya kepada mereka yang akan menunaikan fardhu haji. Beliau juga selalu menghantar orang-orang kampung ke Mekah melalui Pulau Pinang. Pada tahun 1952 oleh kerana tanggungjawab mengajar di pondok lebih diutamakan, beliau telah mengamanahkan urusan penghantaran

\footnotetext{
35 Abdul Rahim Haji Abdul Rahman (anak Haji Abdul Rahman), dalam temu bual dengan penulis, 29 Februari 2012.

36 Abdul Rahim Haji Abdul Rahman (anak Haji Abdul Rahman), dalam temu bual dengan penulis, 29 Februari 2012.

37 Mat Daud Haji Che Wan (adik Haji Abdul Rahman) dalam temu bual dengan penulis, 29 Februari 2012.
} 
tersebut kepada Haji Yusuf bin Haji Taib. ${ }^{38}$ Memenuhi jemputan orang ramai juga tidak dihampakan. Kadang-kadang beliau sanggup berjalan kaki lebih daripada sepuluh batu untuk memenuhi jemputan mereka. ${ }^{39}$

\section{Kematian}

Tanggal 27 Jamadilakhir 1409 Hijriyyah bersamaan 4 Februari 1989 Haji Abdul Rahman dijemput mengadap Ilahi sekitar jam 2.45 petang pada hari Sabtu. Solat jenazah pertama dilakukan di rumah Allahyarham sendiri dengan kehadiran yang terlalu ramai ahli jemaah sehinggakan papan rumah terpaksa ditahan dengan kayu lain kerana hampir runtuh. Setelah itu jenazah disolatkan pula beberapa kali di Masjid Lubuk Tapah oleh hadirin yang hadir untuk memberi penghormatan terakhir kepada beliau. Anak Allahyarham sendiri iaitu Haji Abdullah yang mengimami solat jenayah tersebut. ${ }^{40}$

Haji Abdul Rahman dikebumikan keesokan hari selepas kematian beliau iaitu hari Ahad, sekitar jam 9.00 pagi dalam perkarangan Masjid Lubuk Tapah. Pengebumian ini kerana menunaikan wasiat beliau untuk dikebumikan dalam perkarangan masjid. Cetusan idea ini selepas beliau ke Mesir pada tahun 70an dan melihat sendiri kebanyakan ulama di sana dikuburkan di perkarangan masjid. $^{41}$

Pemergian beliau dalam usia 87 tahun itu meninggalkan jasa dan sumbangan yang besar kepada warga Lubuk Tapah khususnya dan masyarakat umumnya. Beliau meninggalkan seorang balu iaitu Hajjah Zainab binti Mamat dan sepuluh orang anak hasil perkongsian dengan isteri yang pertama dan ketiga.

\section{METODOLOGI PENULISAN KITAB PEDOMAN SOLAT BERJEMAAH}

\section{Metode penyusunan kitab Pedoman Solat Berjemaah}

\section{Format}

Penyusunan sesebuah karya mengikut susunan yang teratur dan sistematik merupakan format yang digunakan oleh setiap pengarang bagi memastikan

38 Muhammad Jusoh, Tuan Guru Haji Abdul Rahman Haji Che Wan seorang Tokoh Ulamak Pondok, 108.

39 Muhammad Yunan Mahmud, Riwayat Hidup Tokoh Ulama Kelantan, 103.

40 Abdul Rahim Haji Abdul Rahman (anak Haji Abdul Rahman), dalam temu bual dengan penulis, 29 Februari 2012.

41 Abdul Rahim Haji Abdul Rahman (anak Haji Abdul Rahman), dalam temu bual dengan penulis, 29 Februari 2012. 
penulisan mereka difahami. Melalui kitab Pedoman Solat Berjemaah ini, penulis dapat merumuskan beberapa format yang digunakan oleh beliau sebagaimana berikut:

\section{a) Bahagian Pendahuluan}

Pada bahagian pendahuluan kitab, pengarang memulakan dengan pujian kepada Tuhan sekalian alam dan selawat serta salam ke atas junjungan besar Nabi Muhammad SAW. Seterusnya pengarang menjelaskan sebab yang mendorong beliau menulis kitab tersebut iaitu:

"Maka tatkala melihat hamba akan setengah saudarasaudara hamba yang menunaikan sembahyang berjemaah pada sesetangah tempat hal keadaan meninggalkan mereka itu akan adab-adab baginya, maka bergerak fikiran hamba akan menuliskan satu risalah yang menyata ia akan setengah adabadab yang tertentu baginya supaya dapat kelebihannya bagi mereka itudan terpelihara daripada batal sembahyang mereka itu sekira-kira mengamat-amat mereka itu."

Kerendahan diri pengarang dapat dilihat melalui kata-katanya dalam pendahuluan tersebut. Ganti nama 'hamba' yang merujuk kepada diri beliau adalah salah satu penggunaan ganti diri yang meluas digunakan di negeri Kelantan. Kalimah ini adalah salah satu ganti diri yang agak beradab apabila seseorang bercakap dengan orang lain. Selain itu, beliau juga menggunakan perkataan 'saudara-saudara hamba' dan tidak dengan perkataan anak-anak murid atau mana-mana istilah yang menunjukkan mereka yang di bawah jagaan atau seliaan beliau.

Di awal pendahuluan kitab tersebut juga, beliau menjelaskan pembahagian kitab kepada beberapa bahagian tertentu yang dinamakan 'faṣl', iaitu:

"dan hamba susunkan di dalamnya tiga fașl dan satu khatimah (penutup)"

Harapan beliau dan seterusnya menjadi satu doa agar karya beliau itu bermanfaat untuk diri beliau sendiri dan juga sekalian pembacanya serta mengharapkan apa yang dikarangnya itu ikhlas dalam mencari keredhaan Allah. Dengan kata-kata beliau:

“...dan akan Allah Taala jua hamba pohonkan bahawa memberi manfaat Ia dengan ini risalah bagi hamba sendiri dan bagi sekalian pembacanya dan bahawa menjadi Ia akan dia ikhlas menuntut keredhaanNya...". 


\section{b) Bahagian Isi Kandungan Kitab}

Pengarang telah membuat susunan dalam kitab beliau dalam bentuk yang agak sistematik. Ini dapat dilihat melalui penjelasan awal daripada beliau lagi bahawa kitab ini dibahagikan kepada tiga faṣl (ceraian) dan satu khatimah (penutup). Metode penulisan beliau dalam setiap awalan bab dijelaskan dengan teliti. Antaranya:

"faṣl yang pertama pada menyatakan hukum solat berjemaah dan kelebihannya."

"fașl yang kedua pada menyatakan syarat-syarat bagi sah qudwah (mengikut imam)."

"fașl yang ketiga pada menyatakan adab sembahyang berjemaah."

"(khatimah) dan bermula segala uzur sembahyang jemaah banyak."

Pada faṣl yang pertama, pengarang menjelaskan hukum solat berjemaah mengikut pandangan yang berbeza-beza dalam kalangan ulama muktabar dan memilih satu pendapat yang paling kuat. Di samping itu, pengarang membawa beberapa hadis, serta kisah-kisah yang berkaitan dengan kelebihan solat berjemaah sebagai penguat kepada tuntutan mengerjakan solat berjemaah.

Faṣl yang kedua menjelaskan syarat-syarat sah qudwah, iaitu syaratsyarat sah mengikut imam. Beliau menyusun 12 syarat yang berkaitan dengan qudwah beserta dengan masalah-masalah dan jawapan yang berkaitan dengan syarat-syarat tersebut. Manakala fașl yang ketiga menekankan perkara yang berkaitan dengan adab-adab sembahyang berjemaah.

\section{c) Bahagian Penutup}

Haji Abdul Rahman tidak menutup karya beliau tersebut dengan bahagian penutup yang khusus. Bahkan beliau tidak merumuskan intipati perbincangan dalam kitab beliau pada bahagian penutup. Akan tetapi, beliau telah meletakkan satu perkara penting yang berkaitan dengan solat berjemaah iaitu keuzuran untuk solat berjemaah. Beliau menggariskan sembilan belas bentuk keuzuran yang dibenarkan oleh syara' untuk tidak menghadiri solat berjemaah, dengan kata beliau: 
"(Khatimah) dan bermula segala uzur sembahyang berjemaah banyak..."

Di samping itu, beliau menerangkan beberapa kaifiat amalan yang menjadi amalan kebiasaan masyarakat Melayu secara umum beserta dengan doa-doa yang sepatutnya. Di akhir bahagian ini, Haji Abdul Rahman menjelaskan kaifiat membaca doa Nisfu Syaaban, kaifiat membaca Surah Yaasin empat puluh satu kali dan kaifiat solat hajat. Ketiga-tiga perkara tersebut menjadi amalan turun-temurun dan berterusan hingga kini dalam kalangan masyarakat Melayu terutama di Kelantan. Beliau menyusun ketiga-tiga perkara tersebut secara sistematik dengan disertakan tajuk yang khusus. Contohnya:

"Ini kaifiat membaca doa Nisfu Syaaban."

"Ini kaifiat baca surah Yasin empat puluh satu kali."

"Ini kaifiat sembahyang hajat."

Pengarang telah meletak baris bagi setiap doa yang dikemukakan untuk setiap tiga perkara tersebut dan hal ini sememangnya memudahkan para pembaca. Akan tetapi beliau tidak menterjemahkan makna bagi doa-doa tersebut. Penulis berpendapat bahawa hal ini menyukarkan para pembaca yang tidak mahir dalam bahasa Arab untuk memahami doa-doa tersebut.

\section{2) Metodologi penulisan kitab Pedoman Solat Berjemaah}

Melalui kajian dan penelitian, penulis mendapati metodologi yang digunakan oleh Haji Abdul Rahman dalam karya beliau iaitu Pedoman Solat Berjemaah memudahkan para pembaca untuk memahaminya dan menunjukkan kelainan pada karya beliau ini. Berikut antara metodologi yang digunapakai oleh pengarang yang mempunyai beberapa kelainan tersendiri berbanding karyakarya lain yang seumpamanya.

\section{a) Penerangan berkaitan hukum solat berjemaah melalui perbezaan pendapat para ulama}

Kedudukan solat berjemaah dalam Islam adalah perkara yang penting dan dititikberatkan lebih-lebih lagi terhadap golongan lelaki yang aqil baligh. Pengarang telah menyebut beberapa pendapat ulama berkaitan dengan hukum solat berjemaah, conothnya:

“...dan disyara'kan solat berjemaah kemudian daripada berpindah Nabi ke Madinah dan ialah ketentuan umat ini seperti 
Jumaat dan kedua hari raya dan iaitu sunat muakkad di sisi Raf' 'i'e, kata qil sunat kifayah, kata qil fardhu ain dan terlebih sah di sisi Nawawi fardhu kifayah..."

Selain menyebut perbezaan pendapat dalam kalangan ulama berkaitan hukum solat berjemaah, pengarang memilih hukum fardhu kifayah melalui pentarjihan pendapat di sisi al-Nawāwī. Sesuai dengan kaedah dalam konteks mentarjihkan hukum yang khilaf dalam mazhab Shāfi '⿳亠丷⿵冂丶 maka didahulukan dengan pendapat daripada al-Nawāwī.

\section{b) Penerangan berkaitan kelebihan solat berjemaah dengan hadis Rasulullah SAW}

Antara bentuk metodologi yang diguna oleh pengarang ialah menjelaskan kelebihan solat berjemaah melalui hadis-hadis Rasulullah SAW. Kaedah yang dibawa oleh pengarang dalam menyebut hadis-hadis yang berkaitan dengan kelebihan solat berjemaah adalah melalui dua kaedah. Kaedah yang pertama ialah dengan menyebut matan hadis beserta maksudnya dan kaedah yang kedua adalah dengan hanya menyebut makna sesebuah hadis sahaja.

Pengarang juga tidak menyebut darjat hadis-hadis tersebut. Walau bagaimanapun, beliau tidak meninggalkan hadis-hadis yang dinukilkan itu tanpa menyebut perawi-perawinya. Pengarang menyertakan perawi hadishadis berkenaan sebagai penguat kepada hujah dan juga rujukan status darjat hadis.. Antara hadis yang disebut matan beserta dengan maksudnya sekali, ialah hadis yang diriwayatkan oleh al-Imam al-Bukhari dan Muslim, iaitu:

"dan telah datang beberapa khabar yang banyak pada menyatakan kelebihannya, setengah daripadanya khabar Bukhārì dan Muslim:

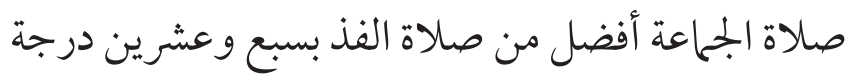

"Ertinya bermula sembahyang berjemaah terlebih afdhal daripada sembahyang seorang dengan dua puluh tujuh darjat." 42

42 Hadis ini dikeluarkan oleh Imām al-Bukhārī pada Bāb Faḍl Șalāh al-Jamā‘ah hadis no. 645 diriwayatkan oleh 'Abd Allāh bin Yūsuf dia berkata mengkhabar akan kami oleh Mālik daripada Nāfi' daripada 'Abd Allāh bin 'Umar dan hadis no. 646 yang diriwayatkan oleh 'Abd Allāh bin Yūsuf, mengkhabarkan akan kami oleh al-Layth, membaca hadis akan aku oleh Ibn al-Had daripada 'Abd Allāh bin Khabbāb daripada Abū Sa‘̄̄d al-Khudrī. Al-Bukhārī, Abū 'Abd Allāh 
Selain daripada hadis yang menjelaskan fadhilat solat berjemaah secara umum, pengarang juga membawa maksud hadis yang menjelaskan khusus tentang fadhilat takbīrah al-iḥrām bersama imam ketika berjemaah. Pengarang tidak menyebut matan hadis tetapi hanya menjelaskan dengan maksud sahaja. Contohnya:

"(dan riwayat) daripada 'Abd al-Rahmmān bin 'Awf $R A$ bahawasanya datang baginya perniagaan di Mesir empat ratus unta dengan muatannya maka keluar ia mendapatkan akan dia maka lambat berpalingnya hingga luput akan dia takbirah alihrām serta Nabi SAW daripada sembahyang fajar dan mendapat ia akan Rasulullah SAW di dalam rukuk pada rakaat pertama maka tatkala selesai ia daripada sembahyang bersedekah ia akan empat ratus unta yang datang di Mesir itu sekaliannya di dalam sabilillah kemudian maka sembah ia ya Rasulullah aku perbuat begini-begini maka adakah tercapai aku akan pahala takbīrah al-iḥrām sabdanya tiada maka sembah ia ya Rasulullah aku jadikan barang yang di atasnya daripada segala mata benda sekaliannya di dalam sabilillah adakah tercapai aku akan pahalanya sabdanya tiada maka sembah ia adalah di atas tiaptiap jamal itu seorang sahaya bagiku aku merdeka akan dia bagi wajhullah taala adakah mencapai aku akan pahalanya sabdanya tiada kemudian sabdanya hai 'Abd al-Rạ̣mān jikalau ada dunia dan barang yang di dalamnya daripada harta kamu dan engkau jadikan dia di dalam sabilillah tiada tercapai kamu akan kelebihannya."

\section{c) Penjelasan kisah al-salaf al-ṣālih terhadap solat berjemaah}

Setelah menjelaskan fadhilat solat berjemaah melalui hadis-hadis Rasulullah SAW, pengarang membawa beberapa kisah tauladan daripada para al-salaf

Muḥammad bin Ismail, al-Jāmi ' al-Ṣaḥīh, Bāb Faḍl Șalāh al-Jamā'ah, no. hadis 645 dan 646 (al-Qāhirah: al-Maṭba'ah al-Salafiyyah wa Maktabatuhā, 1400 h), 1/ 216. Hadis ini juga diriwayatkan oleh Imām Muslim dalam sahihnya pada Bāb Faḍl Șalāh al-Jamā'ah wa Bayān al-Tashd̄̄i fĩ al-Takhalluf 'anhā wa Annahā Farḍ Kifāyah, hadis no. 650 (1477), yang diriwayatkan oleh Yahyā bin Yahyā berkata aku membaca kepada Mālik daripada Nāfi' daripada Ibn 'Umar. Muslim, Abū alHusayn Muslim bin al-Hajjāj Ibn Muslim al-Qushayrī al-Naysabūrī, al-Jāmī' alȘaḥịh, Bāb Faḍl Șalāh al-Jamā'ah wa Bayān al-Tashdīd fi al-Takhalluf 'anhā wa Annahā Farḍ Kifāyah, no. hadis 650 (1477) (Riyāḍ: Dār al-Salām, 2000), 262. 
al-șālih yang menunjukkan keprihatinan mereka terhadap solat berjemaah. Antara kisah yang dibawa oleh pengarang ialah:

"dan telah membilang salaf akan luput sembahyang berjemaah akan bala dan adalah setengah salafkeluar ia pergike kebun tamar baginya kemudian balik ia tiba-tiba manusia sudah sembahyang asar maka mengucap ia inna lillah wa inna ilaihi raajiun luput dah aku sembahyang jemaah ini maka ia pun jadikan kebunnya sedekah kepada miskin-miskin ganti kerugiannya."

Kisah al-salaf al-șālih tersebut tidak dicatat secara jelas mengenai nama dan zaman berlakunya kejadian tersebut. Juga kisah 'Abd Allāh bin 'Umar al-Qawārirī RA yang ketinggalan solat isyak secara berjemaah. Demikian keprihatinan para al-salaf al-șālih terhadap solat berjemaah yang cuba dijelaskan oleh pengarang. Kedudukan ibadat mereka cuba dipraktikkan sebagaimana yang dijelaskan dan diajar oleh Rasulullah SAW.

\section{d) Menukil pendapat ulama muktabar Shāfi'iyyah}

Penulis melihat bahawa pengarang lebih cenderung untuk mengambil pendapat-pendapat beberapa ulama muktabar dalam mazhab Shāfi ‘í. Antara mereka yang menjadi sandaran beliau ialah:

\section{i) Al-Imām Ibn Ḥajar ${ }^{43}$}

Antara contoh pendapat yang dinukilkan daripada ulama agung ini ialah:

“...dan di sisi Ibn Hajar tak dapat tidak daripada berlafaz tiada memada dengan diam..."

43 Beliau ialah Aḥmad bin Muḥammad bin 'Alī al-Haytamī al-Sa'dī al-Anșārī. Dilahirkan di Mesir pada tahun 909 H dan menimba ilmu di Universiti al-Azhar, Mesir. Antara guru beliau dalam bidang fiqh ialah Sheikh al-Islām Shihāb al-Dīn al-Ramlī. Ketika berumur 40 tahun beliau menunaikan haji untuk kali seterusnya dan menetap di sana, di samping mengarang kitab dan juga berfatwa. Beliau mengajar di sana sehingga meninggal dunia pada tahun 973. Sumbangan beliau dalam menghasilkan karya-karya dalam pelbagai sudut ilmu amat banyak dan antara karya beliau ialah Tuḥfah al-Muhtāj li Sharh al-Minhāj dalam ilmu fiqh, Sharh al-Arba 'ìn al-Nawāwīyyah dalam ilmu hadis, Fatāwā al-Haytāmiyyah dan lain-lain. 'Abd al-Ḥamīd al Sharwānī \& Aḥmad Qāsim al-'Ubbādī, Hawāshī 'alā Tuḥfah al-Muḥtāj bi Sharḥ al-Minhāj (Bayrūt: Dār al-Fikr, 1997), 1. 


\section{ii) Sheikh al-Baghāwīi ${ }^{44}$}

Antara nukilan pengarang ketika mengambil pendapat daripada ulama ini, ialah:

“...dan diuzurkan dia ketinggalan dengan imam hingga tiga rukun yang panjang juga atas perkataan Sheikh Räfi 'ì dan Nawawì dan Baghawī..."

\section{iii) Al-Imām al-Ramlī ${ }^{45}$}

Pengarang berpegang dengan pendapat al-Imām al-Ramlī dalam masalah keredaan makmum dengan imam yang memanjangkan rukun, ujar beliau:

“...melainkan jika reda dengan memanjangnya oleh makmum yang mahsur dengan berlafaz atau diam serta mengetahui imam dengan reda mereka itu di sisi Muhammad Ramli..."

44 Nama beliau ialah Abū Muḥammad al-Ḥusayn bin Mas'ūd al-Farrā’ al-Baghāwī. Dilahirkan di Baghshur, salah sebuah negeri yang kecil di Khurasān dan dikatakan beliau lahir pada kurun ke-5. Al-Baghawī meninggal pada tahun $516 \mathrm{H}$ pada umur sekitar 80 tahun. Ulama yang berpegang dengan mazhab Shāfi'ī ini banyak membantu mazhab tersebut tetapi dalam karangan beliau sendiri tidak terlalu taksub kepada satu mazhab sahaja dan antara gelaran beliau ialah Muhyi alSunnah iaitu penghidup Sunnah. Al-Baghāwi telah meninggalkan pelbagai karya dalam bidang tafsir, fiqh dan hadis, antaranya ialah Majmu' ' min al-Fatāwā, alTahdhīb fì Fiqh al-Imām al-Shāfi '̄̄, Ma 'àlim al-Tanzīl, Mașābih al-Sunnah, Sharh al-Sunnah dan lain-lain. 'Abd al-Ḥamīd al Sharwānī \& Aḥmad Qāsim al-'Ubbādī, Hawāshī 'alā Tuhfah al-Muhtāj bi Sharh al-Minhāj, 29-30.

45 Shams al-Din, Muḥammad bin Ahmad al-Ramlī, meninggal pada tahun $1004 \mathrm{H}$. Kitab Nihāyah al-Muhtāj Sharh al-Minhāj karya beliau itu dikira sebagai kitab muktamad dalam mazhab Shāfi'ī di sisi ulama-ulama Shāfi ‘iyyah di Mesir dan selainnya. Kitab ini dibaca kepada lebih kurang empat ratus ulama dan mereka mentashihkan sehingga sampai kepada darjat mutawātir. Muḥammad Ibrāhīm alHafnāwī, Muștalahāt al-Fiqhiyyah wa al-Ușūliyyīn (al-Qāhirah: Dār al-Salām, 2007), 151. 


\section{iv) Sheikh al-Rāfi ${ }^{\top} \overline{\mathbf{I}}^{46}$}

Antara nukilan pengarang dalam mengambil pendapat daripada ulama ini, ialah:

“...dan diuzurkan dia ketinggalan dengan imam hingga tiga rukun yang panjang juga atas perkataan Sheikh Rafi'e dan Nawawi dan Baghawi..."

\section{v) Sheikh al-Islām Zakariyyā al-Anșārīi ${ }^{47}$}

Antara petikan pengarang dalam mengambil pendapat daripada Sheikh Zakariyyā al-Anșārī, ialah:

“...dan jika nyata punah sembahyang pertama tiada memadai oleh yang kedua gantinya atas muktamad sisi Nawawi dan Ibn Hajar khilaf bagi Sheikh al-Islam Zakaria kerana mengikut bagi Ibn I'mad dan Ghazali katanya memada ganti yang kedua jika ia niat sembahyang yang keduaakan fardhu..."

46 Beliau ialah 'Abd al-Karīm bin Muhammad bin 'Abd al-Karīm bin al-Faḍl bin al-Husayn bin al-Hasan. Beliau mendalami ilmu melalui ayah beliau sendiri dan ulama-ulama yang lain sehingga mahir dalam ilmu fiqh, tafsir, hadis, usul fiqh dan sebagainya. Beliau telah meninggalkan beberapa karangan dalam sumbangan beliau kepada ilmu-ilmu Islam, antaranya al-'Azīz Sharh al-Wajīz, al-Sharh al-

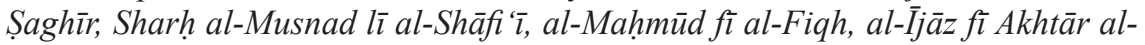
Hijāz, al-Taznīb dan lain-lain lagi. Menurut Ibn Khalkān, beliau meninggal pada Zulqaedah tahun $623 \mathrm{H}$ ketika berumur 66 tahun. 'Abd al-Karīm Muhammad al-Rāfi'̄i, al-'Azīz Sharh al-Wajīz, e.d. 'Alī Muhammad Mu'awwid \& 'Ādil Muḥammad 'Abd al-Mawjūd (Bayrūt: Dār al-Kutub al-'Ilmiyyah, 1997), 421.

47 Beliau adalah Zakariyyā bin Muhammad bin Aḥmad bin Zakariyyā al-Anșārī al-Shāfi‘̄i yang diberi beberapa gelaran, antaranya Sheikh al-Islām dan Qāộ̄ alMufassir. Dilahirkan di Mesir pada tahun $823 \mathrm{H}$ bersamaan $1420 \mathrm{M}$ dan hidup dalam keadaan miskin yang sederhana. Antara karangan beliau ialah Fath alRahmōnn tentang tafsir, Tuhfah al-Bārī 'alā Sahīh al-Bukhārī dan Fath al-Jalīl

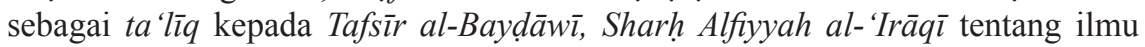
Muștalah Hadīth, Sharh Shudhūr al-Dhahab tentang ilmu nahu dan banyak lagi. Zakariyyā Muḥammad al-Anșāī, al-Ghurar al-Bahiyyah, ed. Muḥammad 'Abd al-Qadīr 'Ațā' (Bayrūt: Dār al-Kutub al-'Ilmiyyah, 1998), 5. 


\section{vi) Ibn ' $\operatorname{Imād}{ }^{48}$}

Antara petikan pengarang dalam mengambil pendapat daripada Ibn 'Imād:

“...khilaf bagi Sheikh al-Islām Zakariyyā kerana mengikut bagi Ibn 'Imād dan Ghazālì katanya memada ganti yang kedua jika ia niat sembahyang yang kedua akan fardhu..."

\section{vii) Al-Ḥabīb ‘Abd Allāh al-Ḥaddād ${ }^{49}$}

Antara kata-kata al- Habīb yang dipetik oleh pengarang dalam permasalahan saf solat, ialah:

“...dan telah berkata Saydina al-Habīb 'Abd Allāh al-Haddād di dalam kitab Nașā'ihnya bermakna...”

48 Beliau ialah Muḥammad bin Aḥmad bin 'Imād bin Yūsuf al-Aqfahashī al-Syāfi ‘̄. Dikenali dengan panggilan Ibn 'Imād al-Aqfahashī. Beliau dilahirkan pada bulan Ramadan di Kaherah, Mesir pada tahun 780. Antara karya beliau ialah al-A 'lām bi mā Yata 'allaq bi al-Iltiqā' Khitānayni min al-Aḥkām, Tanwīr al-Dayājir, alAlfāz al-Wasnān bi al-Āyāt al-Wāridah fì Zamm al-Insān dan banyak lagi. Beliau meninggal pada hari Sabtu, 5 Rabiulawwal tahun 867. Ibn 'Imād al-Aqfahashī, alIrshād ilā Ma Waqa 'a fì al-Fiqh wa Ghayrihi min al-I'dād, ed. 'Ādil Muḥammad 'Abd al-Mawjūd dan 'Alī Muḥammad Mu'awwid (Bayrūt: Dār al-Kutub al'Ilmiyyah, 1992), 1/6-7.

49 'Abd Allāh bin 'Alawī bin Aḥmad al-Muhājir bin 'Īsā bin Muḥammad bin 'Alī al-Tarīmī al-Ḥaddād al-Hasanī al-Yaman̄i dilahirkan di desa Sabīr, Kota Tarīm, Yaman pada tahun $1044 \mathrm{H}$ dan dibesarkan di sana. Beliau yang hilang penglihatan seawal umur 4 tahun terkenal dengan warak, tawaduk dan seorang yang murah dengan senyuman. Salasilah keturunan beliau bersambung kepada Rasulullah Saw melalui Sayidina al-Husayn. Beliau telah mengarang sejumlah kitab tasawuf dan antara karya beliau yang masyhur ialah al-Nașā iḥ al-Dinniyyah wa al-Wașāya al-İmāniyyah. Pada tahun $1132 \mathrm{H}$, beliau meninggal dunia dan dikuburkan di pemakaman Zambal, di Kota Tarim, Haḍaramawt, Yaman. 'Abd Allah 'Alawī alHaddād, al-Nașā'ih al-Dīniyyah wa al-Wașāyā al-Īmāniyyah, ed. Muhammad Nūr al-Dīn Marbū al-Banjarī (al-Qāhirah: Tab` bi al-Lizār, 1997), 1/8-20. 


\section{viii) Sheikh Tāj al-Dīn al-Subkī̄so}

Hal ini dapat dilihat apabila pengarang membicarakan permalasahan mengikut anak zina dan seumpamanya sebagai imam, ujar beliau:

“...dan telah memilih oleh Subki dan mereka yang mengikutnya akan ternafi makruh apabila teruzur jemaah melainkan di belakang mereka yang tersebut..."

\section{ix) Khațīb al-Sharbīnīi ${ }^{51}$}

Antara petikan pengarang dalam menukilkan pendapat Khațīb al-Sharbīnī, ialah:

“...dan yang berlaku atasnya Sheikh Ramli dan seumpamanya

Khațīb al-Sharbīni bahawasanya ia seperti muafiq..."

50 Dilahirkan pada tahun 727 H bersamaan 1327 M di al-Qāhirah, Mesir. 'Abd alWahhāb bin 'Alī bin 'Abd al-Kāfĩ al-Subkī ini pernah menjawat jawatan ketua kadi. Beliau yang meninggal di Damsyik pada tahun $771 \mathrm{H}$ bersamaan 1370 M, telah menghasilkan pelbagai karya dan antaranya yang masyhur ialah Jam ' al-Jawāmi' fì Ușūl al-Fiqh, al-Ashbāh wa al-Naz̄ā'ir fì al-Fiqh dan al-Tabaqāt al-Wuștā. Beliau menimba ilmu daripada ramai ulama, antaranya bapa beliau sendiri, al-Hāfiz al-Muzī dan al-Dhahabī Shams al-Dīn bin al-Naqīb telah memberi kebenaran kepada beliau untuk mengeluarkan fatwa dan mengajar. Umur beliau ketika berfatwa tidak lebih daripada 18 tahun. Jalāl al-Dīn al-Suyūṭin, e.d. Muḥammad Ibrāhīm al-Hafnāwī, Sharḥ al-Kawkab al-Sātī (Manșūrah: Maktabah al-Imān, 2000), 10-11.

51 Beliau ialah Shams al-Dīn Muhammad bin Muhammad al-Sharbīn̄i al-Khāțīb al-Syāfi'̄i. Merupakan salah seorang anak didik daripada Universiti al-Azhar dan menjadi khatib di negeri Sharbīn, iaitu salah sebuah ibu negeri di jajahan Daqhliah, Mesir. Antara karya beliau ialah al-Sirāj al-Munīr fì al-I'ānah 'alā Ma 'rifah Ba 'ḍ Ma 'ān̄̄ Kalām Rabbinā al-Hakìm al-Khabīr, al-Iqnā' fì Hall Alfāz Abī Shujā', Sharh al-Tanbīh, Sharh al-Bahjah, Shawāhid Qaṭr al-Nadā wa Ball al-Șadā, Taqrīrāt 'alā al-Mutawallī fì al-Balāghah li al-Taftāzānī dan Manāsik al-Hajj. Beliau meninggal pada hari Khamis, 2 Syaban tahun 977 H. Muhammad al-Sharbīnī, al-Iqnā' 'fì Hall Alfäz Abì Shujā', e.d. 'Alī Muhammad Mu'awwid \& 'Ādil Muḥammad 'Abd al-Mawjūd (Bayrūt: Dār al-Kutub al-'Ilmiyyah, t.t), 4749. 


\section{x) Al-Imām al-Nawāwīi ${ }^{52}$}

Antara rujukan pengarang terhadap ulama agung ini ialah:

“...dan tiada dapat fadhilat jumaat bagi mereka yang meninggalnya dengan uzur kata al-Nawawì di dalam Majmū '...”

Ulama yang disebut di atas merupakan antara ulama Shāficiyyah yang dijadikan sumber rujukan terutamanya dalam masalah-masalah fiqh. Daripada kesemua ulama tersebut, pengarang lebih cenderung kepada pendapat dua ulama besar iaitu Sheikh Ibn Hajar dan Sheikh Ramlī. Ini kerana majoriti pendapat kedua-dua ulama masyhur tersebut digunapakai oleh Haji Abdul Rahman.

\section{e) Penggunaan bahasa tempatan yang mudah difahami}

Pada penelitian penulis, pengarang menggunakan beberapa perkataan yang digunapakai oleh masyarakat tempatan negeri Kelantan. Loghat yang diguna oleh pengarang memudahkan pemahaman para pembaca lebih-lebih lagi mereka yang memahami loghat ini. Dari sudut yang lain, penulis melihat bahawa pendekatan ini merumitkan mereka yang tidak memahami dengan baik loghat tersebut. Bahasa yang digunakan ini berulang-ulang pada beberapa tempat dalam karya beliau. Secara keseluruhan, pengarang menggunakan 15 patah perkataan loghat negeri Kelantan dan perkataan tersebut berulang-ulang pada beberapa tempat. Antara contoh perkataan yang digunakan ialah:

i) Tupang bermaksud tumpang

“...dan adalah 'Abd Allāh bin 'Umar al-Qawārirī Rahimahullah Taala tiada meluput akan dia sembahyang jemaah kemudian datang ke rumahnya seorang tupang berhenti..."

52 Beliau ialah Muḥy al-Dīn Abū Zakariyyā, Yaḥyā bin Sharaf bin Murrā bin Ḥasan bin Ḥusayn bin Muhammad Ibn Jum'ah bin Ḥizām, al-Nawāwī. Dilahirkan pada tahun $631 \mathrm{H}$ dan ketika berumur 9 tahun, beliau dan bapanya berpindah ke Damsyik dan bersekolah di sana sehingga meninggal di sana. Antara karangan beliau dalam bidang fiqh ialah Rawdah al-Ṭālibìn, al-Majmū' Sharh al-Muhadhdhāb, al-Minhāj, al-Ị̇̂ạh fì al-Manāsik dan al-Fatāwā. Muḥammad Nūr al-Dīn Marbū al-Banjarī, Tawfìq al-Bārī li Tawḍīh wa Takmīl Masā'il al-Ị̇̂̄h fì al-Manāsik li al-Imām al-Nawāwō (al-Qāhirah: Dār al-Quds, 2003), 1/7. Yahyyā bin Sharaf alNawāwī, al-Adhkār al-Muntakhab min Kalām Sayyid al-Mursalīn, e.d. Țāriq alṬanțāwī (al-Qāhirah: Maktabah al-Qur'ān, 2006), 5-6. 
ii) Bergaduh bermaksud bersegera

“...dan adalah 'Abd Allāh bin 'Umar al-Qawārirī Rahimahullah Taala tiada meluput akan dia sembahyangjemaah kemudian datang ke rumahnya seorang tupang berhenti maka bergaduh ia dengan sebabnya..."

iii) Dikatuk bermaksud ditutup

“...dan jika dikatuk pintu-pintu..."

Perkataan-perkataan tersebut merupakan perkataan yang sering digunakan oleh masyarakat Kelantan umumnya dalam percakapan seharian. Maka keistimewaan kitab Pedoman Solat Berjemaah salah satunya kerana mengandungi loghat Kelantan yang diketengahkan dalam penulisannya sekaligus menambahkan karya ilmiah daripada ulama Kelantan.

\section{Penggunaan Istilah dalam Bahasa Arab}

Penulisan beliau dapat dilihat mempunyai pengaruh penulisan Arab dan bagi penulis hal ini tidak mustahil kerana faktor pendidikan beliau menjadi salah satu sebab pengaruh tersebut wujud. Pengarang menggunakan beberapa istilah tertentu dalam bahasa Arab tanpa menterjemahkannya dalam bahasa Melayu. Hanya sebilangan kecil sahaja yang diterjemahkan maksudnya. Beberapa istilah yang digunakan telah dimaklumi dan masyhur penggunaannya di kalangan penuntut ilmu secara khusus dan masyarakat awam secara umum. Bahkan beberapa istilah tersebut memang sudah digunapakai dengan meluas di kalangan masyarakat. Secara keseluruhan istilah yang digunakan oleh pengarang adalah berkisar dalam lingkungan fiqh solat.

Dalam masalah solat berjemaah, istilah نية مفارقة sudah tidak asing lagi. Umumnya mengetahui bahawa istilah tersebut menunjukkan keadaan makmum yang berniat untuk keluar daripada mengikuti imam dan meneruskan solat bersendirian dengan sebab-sebab tertentu. Pengarang juga menyebut beberapa kali kalimah مصصور yang dikhususkan kepada bilangan makmum yang boleh dibilang jumlahnya dari segi adat. Selain itu kalimah أفضل ,تحرّم dan juga digunakan berulang-ulang di beberapa tempat oleh pengarang. Daripada sejumlah istilah dan kalimah yang digunakan pengarang, hanya beberapa sahaja yang diterjemahkan maksudnya. Contohnya seperti istilah رابطة, pengarang menerangkan maksudnya iaitu yang menambat. Istilah ini bagi masalah kedudukan imam dan makmum yang berbeza tempat kedudukan ketika solat. Makmum yang berdiri berbetulan dengan pintu menjadi pengikat 
kepada makmum yang berada di luar binaan. Secara keseluruhan penggunaan kalimah dan istilah Arab yang digunakan oleh pengarang tidak diterjemahkan maksudnya.

\section{Merujuk kepada kitab-kitab muktabar dalam mazhab Shāfi‘ī}

Pengarang menjadikan beberapa kitab muktabar dalam mazhab Shāfi'ī sebagai rujukan beliau. Walaupun pengarang tidak mencatat rujukan secara khusus, akan tetapi beliau menyebut beberapa kitab dan juga menukilkan pendapat daripada kitab-kitab tersebut. Antara kitab yang dijadikan rujukan oleh pengarang ialah:

\section{i) Tuhfah al-Muḥtāj Sharḥ al-Minhāj ${ }^{53}$}

Antara nukilan pendapat yang diambil daripada kitab tersebut ialah:

"...khilaf bagi Jam" Muhaqqiqīn bahawasanya orang masbuk itu tiada diuzurkan kerana taqsīrnya dan menjazam dengan demikian itu oleh Ibn Hajar di dalam Tuhfah..."

\section{ii) Nihāyah al-Muhtāj Sharh al-Minhājj ${ }^{54}$}

Antara tempat yang dirujuk oleh pengarang dalam kitab ini ialah dalam permasalahan berdiri berseorangan di belakang saf tanpa sebarang keuzuran yang mengakibatkan luput fadhilat jemaah, ujar beliau:

53 Tuhfah al-Muhtāj Sharh al-Minhāj ialah karangan al-Imām Ibn Hajar Aḥmad bin Muḥammad al-Ḥaytāmī (m. 974). Kitab ini merupakan syarah bagi kitab Minhāj karangan al-Imām al-Nawāwī yang menjadi pegangan ulama mutaakhirin untuk berfatwa dalam mazhab. Ulama Ḥaḍaramawt, Shām, al-Akrad, Dakistān, kebanyakan ulama Yaman dan Hijāz berpegang dengan apa yang difatwakan oleh Sheikh Ibn Hajar dalam kitab Tuhfah al-Muhtāj kerana merangkumi nas-nas alImām al-Ḥaramayn al-Juwaynī beserta penambahan daripada pengarang sendiri. Muhammad Ibrāhīm al-Ḥafnāwī, Mușțalahāt al-Fiqhiyyah wa al-Ușūliyyīn (alQāhirah, Dār al-Salām, 2007), 151-155.

54 Kitab ini ialah karangan Shams al-Din al-Jamāl Muhammad bin Ạ̣mad al-Ramlī (m. $1004 \mathrm{H})$. Sesungguhnya ulama Mesir dan kebanyakan daripada mereka berpegang dengan apa yang dikata oleh Sheikh al-Ramlī dalam kitab beliau terutamanya dalam kitab Nihāyah al-Muhtāj kerana kitab tersebut dibaca kepada pengarangnya dan ulama-ulama lain sehingga empat ratus ulama dan mereka mensahihkannya hingga sampai kepada had mutawātir. Muḥammad Ibrāhīm alḤafnāwī, Muștalahāt al-Fiqhiyyah wa al-Ușūliyyīn, 155. 
“...dan dengan ini diketahui akan dhoif perkataan mereka yang berkata tidak luput fadhilat jemaah sini kecuali kerana uzur seperti waktu panas dengan masjidil haram maka tiada makruh dan tiada taksir seperti barang yang zahir pada Tuhfah, Nihāyah begitulah."

iii) Al-Nașā 'ị̆ al-Dīniyyah ${ }^{55}$

Antara kata-kata al-Habīb yang dipetik oleh pengarang dalam kitab tersebut ialah:

“...dan telah berkata Saydinā al-Habīb 'Abd Allāh al-Haddād di dalam kitab Naṣā'ihnya bermakna...”

55 Kitab al-Habīb Abdullah bin A'lawī al-Haddād ini merupakan kitab terbesar karangan beliau, sebesar-besar manfaat dan paling luas tersebar selepas kitab beliau Risālah al-Muā'wanah wa al-Muzāharah wa al-Mu'āzarah. Kitab ini merangkumi serta menghimpun setiap kelebihan-kelebihan zahir dan batin, jelas pada ibarat penulisannya, kuat pada uslubnya, yang dipercayai pada nukilannya, jelas dalil, zahir penerangan, disokong dengan ayat-ayat al-Quran dan hadis-hadis Rasulullah sallalahu 'alaihi wa sallam. 'Abd Allāh al-Ḥaddād, Rātib al- Haddād dan Wird al-Lațîf (Kuala Lumpur: Amanah Hawi al Khairat, 2010), 5. 
iv) Fath al-Jawwād Sharh al-Irshād ${ }^{56}$

Antara petikan daripada kitab tersebut ialah:

“...dan berkata Ibn Hajar di dalam Sharḥ al-Irshād... ”

Selain itu, dinukilkan daripada kitab Fath al-Jawwād ialah:

“...tiada luput kesemua sembahyang berkata Ibn Hajar di dalam

Fath al-Jawwād...”

v) Kitab al-Majmū's7

56 Kitab ini merupakan salah satu daripada kitab-kitab fiqh karangan Sheikh Ibn Hajar al-Haytāmī yang terkenal. Fath al-Jawwād adalah ringkasan kitab al-Imdād bi Sharh al-Irshād yang juga merupakan karangan beliau. Kedua-dua kitab ini adalah syarah kepada Matn al-Irshād karangan al-Imām Ismā'īl bin Abū Bakr Ibn al-Muqrī al-Yaman̄̄ yang meninggal pada tahun 837 H. Fath al-Jawwād Sharh al-Irshād merupakan sebuah penulisan fiqh yang dikarang dengan susunan topik yang menarik dan mendapat sambutan yang baik terutamanya di Yaman. Terdapat dua hāashiyah bagi kitab ini, iaitu hạshiyah yang diusahakan oleh Ibn Hajar al-Haytāmī sendiri dan hāshiyah al- 'Allāmah al- 'Uqaybì al-Yamanī. Fatḥ al-Jawwād Sharh al-Irshäd ini berada di tangga yang kedua selepas Tuhfah al-Muhtāj bi Sharh al-Minhāj untuk dimuktamadkan pandangan-pandangan dalamnya jika berlaku percanggahan pandangan beliau dalam karangan-karangan fiqhnya. Al-Sayyid 'Alawī al-Saqqāf, al-Fawā'id al-Makkiyyah fì Ma Yaḥtājuhu Talabah al-Shāfi 'iyyah min al-Masā'il wa al-Dawābiț wa al-Qawā 'id al-Kulliyyah (Mesir: Sharikah Maktabah wa Mațba'ah Mușțafā al-Bābī al-Ḥalabī wa Awlādihi, 1940), 37. Muhammad al-Ṭayyib, al-Madhhab 'ind al-Shāfi 'iyyah wa Dhikr Ba'd 'Ulamāihim wa Kutubihim Wa Iștilāhātihim (al-Țāif: Maktabah Dār al-Bayān alHadīthah, 2000), 252. Amjad Rashīd Muḥammad 'Alī, 'al-Imām Ibn Hajar alHaytāmī wa Atharuhu fī al-Fiqh al-Shāfi '⿳亠,' (Disertasi Sarjana, Fakulti Pengajian Tinggi, Universiti Jordan, 2000), 62 dan 95. Jamaluddin Hashim dan Abdul Karim Ali, 'Metode Penulisan Fiqh oleh Nūr al-Dīn al-Rānirī dalam Kitāb al-Șirāṭ alMustaqìm,' Jurnal Syariah, 17/2 (2009): 274-275.

57 Kitab al-Majmū' Sharh al-Muhadhdhab bagi Imām al-Shīrāzī karya Imām alNawāwī ini dikira sebesar-besar rujukan bagi fiqh dalam mazhab al-Imām alShāfi ‘̄i. Kitab ini dianggap ensiklopedia yang menghimpunkan pendapat-pendapat bagi imam-imam mazhab empat beserta dengan dalil-dalil mereka dengan sedikit munaqashah terhadap pandangan tersebut. Dalam kebanyakan masalah, beliau akan mentarjīhkan pandangan mazhab al-Shāfi‘ī atau mengemukakan pandangannya sendiri. Pandangannya sendiri tersebut dipanggil mukhtārāt. Bagaimanapun, beliau tidak sempat menyempurnakan karya al-Majmī' ini ketika hayatnya dan kemudiannya disempurnakan oleh al-Imām Taqiyy al-Dīn al-Subkī. Al-Nawawī, Muhyy al-Dīn, Yahyyā bin Sharf, al-Majmū' Sharh al-Muhadhdhab li al-Shīrāzī, ed. Muḥammad Najīb al-Muțị‘ī (al-Qāhirah: Dār 'Ilm al-Kutub, 2006), 7-8. 
Pengarang merujuk kepada kitab ini dalam penutup kitab tersebut yang dapat dilihat dalam kenyataan berikut:

“...dan tiada dapat fadhilat jumaat bagi mereka yang meninggalnya dengan uzur kata Nawawī di dalam Majmū'...”

\section{Menyebut khilaf bagi masalah-masalah tertentu}

Timbul perbezaan hukum bagi permasalahan semasa samada berkaitan dengan ibadat, muamalat dan sebagainya disebabkan kemampuan ulama berijtihad dengan ilmu masing-masing. Hikmahnya khilaf tersebut membawa rahmat kepada masyarakat umum berkaitan sesuatu permasalahan hukum. Melalui penelitian penulis terhadap kitab Pedoman Solat Berjemaah ini, pengarang menyebut khilaf ulama bagi sesuatu masalah yang melibatkan pendapat daripada beberapa ulama Shāfi'iyyah yang masyhur.

Sebagai contoh khilaf yang disebut oleh pengarang adalah dalam masalah imam yang mengambil sunat-sunat haiat dan ab'ad dengan sempurna, memerlukan redha atau persetujuan daripada makmum yang mahsur (jumlah makmum yang dapat dianggar). Lihat contoh berikut:

“...dan jangan mengambil akan terlebih akmal melainkan jika redha dengan memanjangkan oleh makmum yang mahsur dengan berlafaz atau diam serta mengetahui imam dengan redha mereka itu disisi Muhammad Ramlì dan sisi Ibn Hajar tak dapat tidak daripada berlafaz tiada memada dengan diam.."

Contoh lain yang disebut oleh pengarang bersama dengan khilaf hukumnya ialah pada masalah mendahului makmum akan imam pada rukun perbuatan $\left(f^{\prime} l \bar{\imath}\right)$. Contohnya:

“...dan mendahului dengan setengah rukun makruh di sisi Ibn Hajar dan haram juga di sisi Sheikh Ramlī dalam Nihāyah dan Khațīb Sharbīnī dalam Mughnī..'

\section{Menghuraikan beberapa masalah tertentu}

Konsep yang dibawa oleh pengarang di sini lebih kepada bentuk ta'liq. Kaedah ini banyak digunakan oleh ulama dalam menghurai lebih terperinci sesuatu masalah. Bagi beberapa tempat yang kesamaran maksudnya, pengarang menjelaskan maksudnya dalam bentuk catatan tepi. Walau bagaimanapun, 
pengarang hanya meletakkan huraian di dua tempat dan dua masalah sahaja catatan di tepi kitab beliau. Contohnya:

"Qawluhu (dan pada tinggal), dan seperti sujud sahwi dan wajib padanya muafakat pada buat tiada pada tinggal maka apabila meniggal akan dia oleh imam sunat bagi makmum sujud kemudian daripada salam imamnya dan sebelum daripada salamnya."

Pengarang menjelaskan maksud tersebut untuk masalah yang ketiga daripada dua belas syarat qudwah iaitu syarat mengikut imam, contohnya:

“..dan ketiganya muafakat makmum dengan imam pada segala sunat-sunat yang jahat menyalahinya seperti sujud tilawah maka wajib muafakat pada buat dan pada tinggal."

Tempat yang keduanya, dihurai oleh pengarang juga pada tepi penjuru kiri kitab beliau, contohnya:

"Qauluhu (batal sembahyangnya) dan jika memperbuat imam akan qunut harus bagi makmum meninggalnya dan sujud ia dengan sengaja dan menanti ia akan imam di dalam sujud."

Huraian ini adalah bagi masalah dalam solat subuh ketika qunut, sebagaimana yang disebut oleh pengarang:

“...maka jika menyalahi makmum akan imam kerana membaca qunut dan tiada turun ia bagi sujud yang pertama melainkan kemudian daripada tunduk imamnya bagi sujud yang kedua nescaya batal sembahyangnya..."

\section{KESIMPULAN}

Karya-karya fiqh dalam mazhab Shāfi'îterutamanya yang bertulisan Jawi adalah antara penyumbang kepada pengembangan pendidikan fiqh di alam Melayu. Kesinambungan perjuangan yang diteruskan oleh para ulama Nusantara memastikan perjalanan ilmu fiqh sampai kepada generasi baru merupakan antara sumbangan yang perlu dihargai. Sekalipun muncul lambakan karyakarya kontemporari dalam tulisan Rumi, namun ia tidak menjejaskan kualiti dan prestasi karya ulama dalam tulisan Jawi.

Kajian ini telah menonjolkan riwayat hidup Tuan Guru Haji Abdul Rahman Lubuk Tapah dan sumbangan beliau dalam mengembangkan dakwah menerusi institusi pondok. Hasil karya beliau yang digunapakai menerima sambutan sehingga ke generasi sekarang. Antara karya beliau yang masih digunakan 
ialah kita Pedoman Solat Berjemaah. Metode penulisan kitab ini menunjukkan keilmuan beliau dalam penguasaan ilmu fiqh solat berjemaah dan dalam masa yang sama memudahkan para penuntut ilmu memahami intipati yang disampaikan.

Haji Abdul Rahman yang melestari pengajian bersistem halaqah terus dikembangkan oleh generasi selepas beliau dan terbukti pondok yang diasasnya sebelum daripada kemerdekaan negara terus kekal sehingga kini. Sumbangan dakwah yang disertakan dengan karya-karya beliau menjadi bukti bahawa penerimaan masyarakat terhadap sistem yang bercorak turath sekalipun perubahan zaman yang pesat dengan kepelbagaian maklumat dan medium keilmuan.

\section{RUJUKAN}

'Abd al-Hamīd al Sharwānī \& Aḥmad Qāsim al-'Ubbādī, Hawāshī 'ala Tuḥfah al-Muhtāj bi Sharḥ al-Minhāj (Bayrūt: Dār al-Fikr, 1997).

'Abd al-Karīm Muḥammad al-Rāfi'̄̄, al-'Azīz Sharh al-Waj̄̄z, e.d. 'Alī Muḥammad Mu'awwid \& 'Ādil Muhammad 'Abd al-Mawjūd (Bayrūt: Dār al-Kutub al-'Ilmiyyah, 1997).

'Abd Allah 'Alawī al-Haddād, al-Nașā'iḥ al-Dīniyyah wa al-Wașāyā alİmāniyyah, e.d. Muhammad Nūr al-Dīn Marbū al-Banjarī (al-Qāhirah: Tab“ bi al-Lizār, 1997).

'Abd Allāh al-Haddād, Rātib al- Haddād dan Wird al-Lațîf (Kuala Lumpur: Amanah Hawi al Khairat, 2010).

Abd Rahman Hj Abdullah, Pemikiran Islam di Malaysia (Kuala Lumpur: Dewan Bahasa dan Pustaka, 1998).

Ahmad Hassan, 'Sumbangan Pengajian Hadis terhadap Pembinaaan Insan: Suatu Kajian di Pondok Lubuk Tapah, Pasir Mas’ (Disertasi Sarjana, Jabatan Sejarah dan Tamadun Islam, Akademi Pengajian Islam Universiti Malaya, 2005).

Amjad Rashīd Muhammad 'Al̄̄, 'al-Imām Ibn Hajar al-Haytamī wa Atharuhu fì al-Fiqh al-Shāfi‘̄', (Disertasi Sarjana, Fakulti Pengajian Tinggi, Universiti Jordan, 2000).

Al-Bukhārī, Abū 'Abd Allāh Muhammad bin Ismail, al-Jāmi' al-Ṣaḥ̄ḥ (alQāhirah: al-Maṭba'ah al-Salafiyyah wa Maktabatuhā, 1400 H).

Ibn 'Imād al-Aqfahashī, al-Irshād ilā Ma Waqa 'a fì al-Fiqh wa Ghayrihi min al-I'dād, e.d. 'Ādil Muḥammad 'Abd al-Mawjūd dan 'Alī Muḥammad Mu'awwid (Bayrūt: Dār al-Kutub al-'Ilmiyyah, 1992). 
Jalāl al-Dīn al-Suyūṭi, Sharḥ al-Kawkab al-Satī, e.d. Muḥammad Ibrāhīm alHafnāwī (Manșūrah: Maktabah al-Imān, 2000).

Jamaluddin Hashim dan Abdul Karim Ali, 'Metode Penulisan Fiqh oleh Nūr al-Dīn al-Rānirī dalam Kitāb al-Șirāṭ al-Mustaqīm,' Jurnal Syariah, 17/2 (2009): 274-275.

Majlis Agama Islam dan Adat Istiadat Negeri Kelantan, 'Tuan Guru Haji Abdul Rahman Lubuk Tapah,' Majalah Pengasuh, Jamadilawal-Jamadilthani 1429H bersamaan September-Oktober 1998M.

Md Ramly Mahmood, 'Peranan Pondok dalam Pendidikan Islam di Kelantan: Suatu Kajian di Pasir Mas, Kelantan' (Tesis Sarjana, Jabatan Syariah dan Tamadun Islam Akademi Pengajian Islam Universiti Malaya, 2005).

Mohamad Suhaimi Mustapar, 'Metode Pengajian Fiqh di Pondok Lubuk Tapah, Pasir Mas, Kelantan' (Disertasi Sarjana, Jabatan Fiqh dan Usul, Akademi Pengajian Islam Universiti Malaya, 2008).

Muḥammad al-Sharbīnī, al-Iqnā' 'fì Hall Alfāz Abì Shujā', e.d. 'Alī Muhammad Mu'awwid \& 'Ādil Muḥammad 'Abd al-Mawjūd (Bayrūt: Dār al-Kutub al-'Ilmiyyah, t.t).

Muḥammad al-Ṭayyib, al-Madhhab ind al-Shāfi iyyah wa Dhikr Ba'd 'Ulamāihim wa Kutubihim Wa Iștilāhātihim (al-Ṭāif: Maktabah Dār alBayān al-Hadīthah, 2000).

Muḥammad Ibrāhīm al-Hafnāwī, Muștalahāt al-Fiqhiyyah wa al-Ușūliyyīn (al-Qāhirah, Dār al-Salām, 2007).

Muhammad Jusoh, 'Tuan Guru Haji Abdul Rahman bin Haji Che Wan seorang Tokoh Ulamak Pondok' (Latihan Ilmiah, Universiti Kebangsaan Malaya, 1994/95).

Muḥammad Nūr al-Dīn Marbū al-Banjarī, Tawfìq al-Bārī li Tawḍ̄ḥ wa Takmīl Masā'il al-Ị̣̂̄ḥ fì al-Manāsik li al-Imām al-Nawawī (al-Qāhirah: Dār al-Quds, 2003).

Muhammad Yunan Mahmud, Riwayat Hidup Tokoh Ulama Kelantan,(Kota Bharu: Yayasan Islam Kelantan, 1989).

Muslim, Abū al-Husayn Muslim bin al-Hajjāj Ibn Muslim al-Qushayrī alNaysabūrī, al-Jāmī' al-Ṣaḥịh (Riyāḍ: Dār al-Salām, 2000).

Al-Nawawī, Muḥy al-Dīn, Yahyyā bin Sharf, al-Majmū 'Sharh al-Muhadhdhab li al-Shīrāzī, e.d. Muḥammad Najīb al-Muṭ̄i'̄̄ (al-Qāhirah: Dār al-'Ilm al-Kutub, 2006).

Al-Nawawī, Yahyā bin Sharaf, al-Adhkār al-Muntakhab min Kalām Sayyid al-Mursalīn, e.d. Țāriq al-Ṭanțāwī (al-Qāhirah: Maktabah al-Qur'ān, 2006). 
Al-Sayyid 'Alawī al-Saqqāf, al-Fawā'id al-Makkiyyah fì Ma Yaḥtājuhu Talabah al-Shāfi 'iyyah min al-Masā'il wa al-Ḍawābit wa al-Qawā'id al-Kulliyyah (Mesir: Sharikah Maktabah wa Maṭba'ah Mușțafā al-Bābī al-Halabī wa Awlādihi, 1940).

Zakariyyā Muhammad al-Anșārī, al-Ghurar al-Bahiyyah, ed. Muhammad 'Abd al-Qadīr 'Ațā' (Bayrūt: Dār al-Kutub al-'Ilmiyyah, 1998).

\section{Temu bual}

Abdul Rahim Hj Abdul Rahman (anak Haji Abdul Rahman), dalam temu bual dengan penulis, 29 Februari 2012.

Lukman Haji Abdullah (cucu Haji Abdul Rahman), dalam temu bual dengan penulis, 25 Februari 2012.

Mat Daud Haji Che Wan (adik Haji Abdul Rahman), dalam temu bual dengan penulis, 29 Februari 2012.

Mohd Zaidi Abdullah (Ketua Penyelidik, Akademi Pencerahan Ulum Pondok dan Tamadun), dalam temu bual dengan penulis, 16 Mac 2012. 